\title{
RUSSIAN GEO-ECONOMICS IN THE EURASIAN SPACE
}

\author{
Mihaela LUȚAȘa, Andrei Viorel TĂTAR ${ }^{\mathrm{b} *}$ \\ a), b) Babeș-Bolyai University, Faculty of Economics and Business Administration, \\ Cluj-Napoca, Romania
}

Please cite this article as:

Article History:

Luţaş, M. and Tătar, A.V., 2020. Russian GeoReceived: 24 November 2019 Economics in the Eurasian Space. Review of Accepted: 27 February 2020 Economic Studies and Research Virgil Madgearu, 13(1), pp.61-73.

doi: 10.24193/RVM.2020.13.52.

Abstract: In recent years the world economy is facing a re-emergence of an actor that once stood as one of the two poles of economic influence in the world, the Russian Federation. Russia's position in the global economy is largely determined by the peculiarities of its space, its properties and qualities. Territorial density and organization of economic life, infrastructural development of the territory and its innovation - to a large extent, affect the competitiveness of the Russian economy and its ability to become a center of regional integration. In order to assess the Russian economic situation we need to consider the dynamics of the regions because Russia can not be interpreted as whole. We propose in this paper, an interpretation of economic dynamics of the Russian regions in order to understand the source of Russian re-emergence on the international economic stage. The model of analyze will consist in assessing the economic performance of the Russian regions selected for the study in correlation with indicators that emerge from a large spectrum from population density and patent application to geography.

Key words: Russian Federation; re-emergence; Geo-Economics; Eurasia JEL Classification: $\mathrm{FO} 2$

(C) 2020 Alma Mater Publishing House. All rights reserved.

* Corresponding author. E-mail address: tandreiviorel@gmail.com. 


\section{References:}

1. Durkheim, E., 1991. O razdelenii obshchestvennogo truda. Metod sotsiologii [On the division of social labor. The method of sociology]. Moscow: Nauka.

2. Gulugina, A., 2012. Standard of living of 2000-2004. The standard of living of Russian regions 6(172), [online] Available at: <https:// www.elibrary.ru/item.asp?id=17769944> [Accessed 1.11.2019].

3. Morev, M.V. and Korolenko, A.V., 2014. Subjective factor in social development as a key resource for the consolidation of the Russian society. Economic and social changes, 5(35), pp.78-98. 10.15838/ esc/2014.5.35.6.

4. Samburova, E.N., 2004. The geographical logic of the disproportionality of the territorial development of China in the post-reform period. Problems of Geoconflictology, 2, pp.173-192. [Самбурова E.H., Географическая логика диспропорциональности территориального развития Китая в пореформенный период, Проблемы геоконфликтологии].

5. State Statistics Committee of Russia, 2020. Gross regional product per capita by constituent entities of the Russian Federation in 1998-2018 [Валовой региональный продукт на душу населения по субъектам Российской Федерации в 1998-2018гг], [online] Available at: <https://mrd.gks.ru/folder/27963> [Accessed 1.11.2019].

6. Trevisha, A.I. and Artobolevskogo, S.S., 2001. Regionalization in the development of Russia. Geographical processes and problems. Moscow: URSS Editorial, pp.50-70. [Регионализация в развитии России. Географические процессы и проблемы. Под.ред. А.И.Тревиша и С.С.Артоболевского, М., 2013 г.]

7. Vardomsky, L.B. and Treyvish, A.I., 1999. Russian economic space of stability problems in the context of the liberalization of foreign trade. In Vardomsky, L.B. and Treyvish, A.I., 1999. Foreign Economic Relations and Regional Development in Russia. Moscow: Epikon, p. 203.

8. Volovik, N. and Prikhodko, S., 2004. Russian economy in 2004. Tendencies and prospects, 26 [pdf] Available at: <https://www.iep. $\mathrm{ru} /$ files/text/trends/2004/2004.pdf $>$ [Accessed 1.11.2019].

9. World Bank, 2018. Rolling back Russia's spatial disparities. Reassembling the Soviet Jigsaw under a Market Economy. [pdf] 
Available at: https://openknowledge.worldbank.org/bitstream/ handle/10986/29866/126805-WP-WBrollingback-PUBLIC. pdf? sequence $=8$ [Accessed 1.11.2019].

10. Yandex, 2015. Facts \& Figures: Russian Internet Growth and Development. Russian Search Marketing, [online] Available at: <http://russiansearchmarketing.com/facts-figures-russianinternet-growth-and-development/> [Accessed 1.11.2019].

11. Zubarevich, N.V., 2005. Russia of the Regions: In What Social Space Do We Live? Independent Institute of Social Policy. Moscow: Pomatur pp. 27-35. [РОССИЯ РЕГИОНОВ: В КАКОМ СОЦИАЛЬНОМ ПРОСТРАНСТВЕ МЫ ЖИВЕМ? НезависимЫЙ институт социальной политики. М., Поматур]. 